\title{
Variation in life-history traits of European anchovy along a latitudinal gradient: a bioenergetics modelling approach
}

\author{
Martin Huret $^{1, *}{ }^{1,}$ Kostas Tsiaras ${ }^{2}$, Ute Daewel ${ }^{3}$, Morten D. Skogen ${ }^{4}$, Paul Gatti ${ }^{1}$, \\ Pierre Petitgas ${ }^{5}$, Stelios Somarakis ${ }^{6}$ \\ ${ }^{1}$ Ifremer, STH/LBH, 29280 Plouzané, France \\ ${ }^{2}$ Hellenic Centre for Marine Research, Anavyssos, Greece \\ ${ }^{3}$ Helmholtz Centre Geesthacht, Institute of Coastal Research, 21502 Geesthacht, Germany \\ ${ }^{4}$ Institute of Marine Research, 5817 Bergen, Norway \\ ${ }^{5}$ Ifremer, EMH, 44311 Nantes, France \\ ${ }^{6}$ Hellenic Centre for Marine Research, Heraklion, Greece
}

\begin{abstract}
Anchovy Engraulis encrasicolus distribution in European waters spans from the Mediterranean Sea to the North Sea, and is expected to expand further north with global warming. Observations from the eastern Mediterranean (North Aegean Sea), the Bay of Biscay and the North Sea reveal latitudinal differences in growth, maximum size, fecundity and timing of reproduction. We set up a mechanistic framework combining a bioenergetics model with regional physical-biogeochemical models providing temperature and zooplankton biomass to investigate the underlying mechanisms of variation in these traits. The bioenergetics model, based on the Dynamic Energy Budget theory and initially calibrated in the Bay of Biscay, was used to simulate growth and reproduction patterns. Environment partly explained the increased growth rate and larger body size towards the north. However, regional calibration of the maximum assimilation rate was necessary to obtain the best model fit. This suggests a genetic adaptation, with a pattern of cogradient variation with increasing resource towards the north, in addition to a countergradient thermal adaptation. Overall, the seasonal energy dynamics supports the pattern of body-size scaling with latitude, i.e. food-limited growth but low maintenance costs in the warm Aegean Sea, and larger size in the North Sea allowing sufficient storage capacity for overwintering. Further, the model suggests a synchronisation of reproductive timing with environmental seasonality as a trade-off between thresholds of temperature and reserves for spawning and overwintering, respectively. Finally, low temperature, short productive and spawning seasons, and insufficient reserves for overwintering appear to be current limitations for an expansion of anchovy to the Norwegian Sea.
\end{abstract}

KEY WORDS: Engraulis encrasicolus - Countergradient variation - Growth - Reproduction · Dynamic Energy Budget theory $\cdot$ Bay of Biscay $\cdot$ Aegean Sea $\cdot$ North Sea

\section{INTRODUCTION}

Climate change has already impacted the phenology (Edwards \& Richardson 2004), body size (Cheung et al. 2013) and distribution (Perry et al. 2005)

${ }^{*}$ Corresponding author: martin.huret@ifremer.fr

${ }^{\S}$ Advance View was available online July 17, 2018

$\S \S$ Article was changed to Open Access, and the copyright notice updated after publication.

This corrected version: June 3, 2019 of marine species, with increasing abundances observed towards the northern part of their range of distribution. Over the northeast Atlantic continental shelf region, a subtropicalisation of the pelagic fish assemblage was evidenced in particular in the North

(C) The authors 2019. Open Access under Creative Commons by Attribution Licence. Use, distribution and reproduction are unrestricted. Authors and original publication must be credited.

Publisher: Inter-Research · www.int-res.com 
and Baltic Seas (Montero-Serra et al. 2015). As the sustainable management of marine resources relies on accurate estimations of exploited species' current and future distributions, abundances and sizes, we need a comprehensive understanding of the factors underpinning these species' responses to climate change over their range of distribution.

Body size is often described as increasing with latitude, a pattern known as Bergmann's rule (Bergmann 1847), despite an expected slower growth with lower temperature (Silva et al. 2008, Conover et al. 2009). This apparent contradiction would represent an adaptive compensation enabling individuals to maximise their growth during the short productive season in northern latitudes (Conover \& Present 1990). In this case, the covariance between genetic adaptation and temperature throughout a latitudinal gradient is negative, which is an example of countergradient variation (Conover et al. 2009). The higher growth rates generally result in higher maximum body sizes, leading to a body-size scaling relationship with latitude (van der Veer et al. 2003). As both reserve quantity and somatic maintenance generally scale with size, this latitudinal size gradient reflects that: (1) organisms are small in lower latitudes because of food limitation, but they also benefit from these small body sizes given the high maintenance cost associated with high summer temperatures, and (2) organisms should be larger in productive environments to accumulate enough energy reserves to survive the harsh winter season. The understanding of the interactions between plastic and evolutionary responses across environmental gradients is a prerequisite to anticipating the evolution of species' ranges.

There are a growing number of studies investigating the effect of latitude on variation of phenotypes (Conover et al. 2009 and references within), but most are descriptive or rely on common-garden or transplant experiments. These experiments have practical limitations for some species that are difficult to rear, and phenotypic plasticity is generally measured for a single environmental driver whereas in the wild, several drivers interact. Few modelling studies on this topic exist (e.g. Munch \& Conover 2002, Mollet et al. 2013), although they offer great potential for disentangling ecological and genetic influences in an integrating way over the individual's life cycle. The generality of mechanistic or process-based biophysical models make them well suited to investigate the impact of environmental forcing (i.e. temperature and food) on species' life history traits (growth, reproduction and survival; Peck et al. 2013, Rose et al. 2015). Ultimately, these models can translate environmental variability, within or across regions, into variability of species traits, and extrapolate the degree of fitness of organisms facing climate change.

European anchovy Engraulis encrasicolus, widely distributed from Western Africa to the Mediterranean and Black Seas and to the north of the North Sea, is one of the species that has shown a substantial increase in abundance in the northern part of its distribution since the mid-1990s (Beare et al. 2004). This increase has been linked to climate variability (Alheit et al. 2012) and the appearance of new environmental windows of opportunity enabling the completion of this species' life cycle (Petitgas et al. 2012, Raab et al. 2013). Niche modelling of anchovy, applied to future climate change scenarios of increasing water temperature, suggests that this trend will continue, eventually leading to a spread further north into the Norwegian Sea (Raybaud et al. 2017). However, robust projections require (1) accounting for the complexity of the life cycles (Petitgas et al. 2013), (2) understanding the variety of factors, not only temperature, affecting life history traits or regulating population dynamics, and (3) linking these projections to physiological principles (Peck et al. 2013). Finally, focusing solely on the northern range of a species might be misleading if characteristics of the core of the species' distribution also change with the environment. In anchovy, a decrease in growth (size-at-age) was evidenced over the last 2 decades in both the northwestern Mediterranean Sea (Van Beveren et al. 2014) and the Bay of Biscay (Doray et al. 2018).

In this study, we compared the traits of anchovy across environmentally contrasting regions of the northeast European continental shelf, from the North Aegean Sea (hereafter Aegean Sea) in the eastern Mediterranean, through the Bay of Biscay to the North Sea. The comparison was based on simulations with a full life-cycle bioenergetics model, forced by temperature and food resources, the values of which are provided by regional coupled physical-biogeochemical models, and supported by available observations. Our bioenergetics model is based on the Dynamic Energy Budget (DEB) theory (Kooijman 2010), and was previously parameterised for anchovy in the Bay of Biscay by Gatti et al. (2017). With our comprehensive modelling framework, we aim to better understand which factors drive the regional differences in the observed growth and reproductive traits. These factors include environmental variables, namely temperature and food resources, and the local genetic adaptation that would be revealed 
through a modification of the parameters of the bioenergetics model for best fit across regions. Given the forecasted expansion to the Norwegian Sea (Raybaud et al. 2017), we additionally performed simulations of the latter region to identify the current ecophysiological constraints preventing the successful completion of the anchovy life cycle in this area.

\section{MATERIALS AND METHODS}

\subsection{The regions}

Four regions were selected to run the fish model, along a latitudinal gradient in the Northeast AtlanticMediterranean geographic area (Fig. 1), namely the Aegean Sea $\left(23-27^{\circ} \mathrm{E}, 40.27-41.5^{\circ} \mathrm{N}\right)$ in the Mediterranean Sea, the Bay of Biscay $\left(6-0.5^{\circ} \mathrm{W}, 43.1-\right.$ $\left.48.5^{\circ} \mathrm{N}\right)$, the North Sea $\left(4^{\circ} \mathrm{W}-10^{\circ} \mathrm{E}, 51-59^{\circ} \mathrm{N}\right)$ and the Norwegian Sea limited to the surroundings of the Lofoten Islands $\left(12-20^{\circ} \mathrm{E}, 67-70^{\circ} \mathrm{N}\right)$.

\subsection{Fish data}

Data on anchovy length and weight at age for the Aegean Sea are those used in Politikos et al. (2015b). They were obtained from the analysis of samples (3862 fish) collected during the concurrent Daily Egg Production Method (DEPM) and Mediterranean International Acoustics Survey (MEDIAS) carried out in June 2003-2006 (Somarakis et al. 2012). Fish were randomly selected from the catch of the pelagic trawl (21 trawl hauls each year) and subsequently transferred to the laboratory for length and weight measurements and otolith extraction. Otoliths were aged using a standardized protocol (ICES 2010). No fish older than 3 yr were found amongst sampled fish in this area. In the Bay of Biscay, the dataset on length and weight at age is that used in Gatti et al. (2017). The data on adult fish (10 446 fish) are from multipleyear small pelagic surveys in spring (2000 to 2011), the data for larval fish are from dedicated spring and summer surveys (1999, 2008 and 2010), and juvenile data were collected from autumn surveys (1999, 2003 and 2005).

There are no dedicated small pelagic surveys in the North Sea. However, catches are reported from the NS-IBTS (North Sea-International Bottom Trawl Survey), which covers the entire North Sea 4 times a year. Catch per unit effort (CPUE) data were extracted from the dedicated database DATRAS (The Database of Trawl Surveys, www.ices.dk/marine-

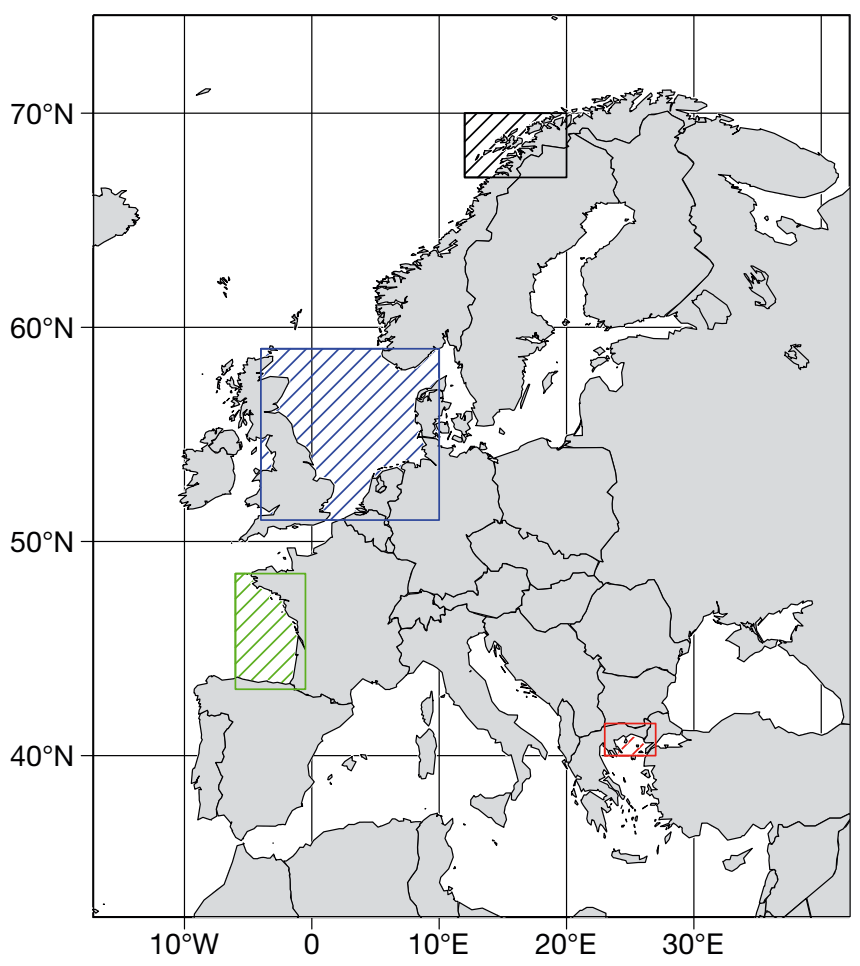

Fig. 1. Case study areas. Red: North Aegean Sea; green: Bay of Biscay; blue: North Sea; black: Norwegian Sea with a focus on the Lofoten area. Regional color coding is the same for all figures hereafter. Northern and southern North Sea areas, as referred to in this manuscript, are separated by the $50 \mathrm{~m}$ depth isobath

data/data-portals/Pages/DATRAS.aspx). Only information after 1990 (until 2016) and Quarters 1, 3 and 4 of the year were considered, since anchovy were too sporadic in the samples from previous decades and during Quarter 2. Length information is associated with the CPUE. From the 5449 reported catches, 549 fish were weighed and aged from otolith reading, but this was only after 2003 and mostly from Quarter 1, which is relatively few considering the duration of the time-series and number of trawl hauls with anchovy. Calculated mean length-at-age (and weight-at-age) were $13.8 \mathrm{~cm}$ $(15.7 \mathrm{~g}), 18 \mathrm{~cm}(36.8 \mathrm{~g})$ and $19.8 \mathrm{~cm}(50 \mathrm{~g})$ for ages 1,2 and 3, respectively, for Quarter 1, and $15.3 \mathrm{~cm}$ (25 g) at age 1 for Quarter 3. To test for the representativeness of these estimations and to achieve a better coverage at seasonal scale, a cohort analysis was assessed on length-frequency information from the CPUE data. We used the Bhattacharya (1967) method from the TropFishR package (Mildenberger et al. 2017). The estimated mean length-at-age was 7.3 and $11.2 \mathrm{~cm}$ for Quarters 3 and 4 at age $0 ; 12.8$, 16.1 and $18.0 \mathrm{~cm}$ for Quarters 1, 3 and 4 at age 1; 
and $18.5 \mathrm{~cm}$ for Quarter 1 at age 2. Despite some differences for Quarter 1 at ages 1 and 2, the estimations are consistent, which provides confidence in the age estimation from the cohort analysis. Length-at-age estimations were then provided by the latter methodology, while weight-at-age was only available from the otolith dataset.

\subsection{Environment forcing from physical- biogeochemical models}

Regional coupled physical-biogeochemical models were applied to each of the targeted regions and hindcast simulations over multiple years were performed. From those, we computed daily climatologies (pluriannual daily means) of temperature and zooplankton biomass. Anchovy is essentially zooplanktivorous, as observed in the Bay of Biscay (Plounevez \& Champalbert 1999) and in the North Sea (Raab et al. 2011), and this is the case over all life stages as evidenced in the Mediterranean Sea (Borme et al. 2009, Nikolioudakis et al. 2014). Hence, we used the cumulated microzooplankton and mesozooplankton from the biogeochemical models as food proxy for the fish bioenergetics model. Because of the lack of data on the variability of the zooplankton energy content and size distribution, the latter was assumed to remain constant throughout the year and across regions.

For the Aegean Sea, the climatologies were calculated on a $20 \mathrm{yr}$ (1980-1999) hindcast simulation of the 3-dimensional ecosystem model POM-ERSEM (Tsiaras et al. 2014). In the Bay of Biscay, the hindcast of ECO-MARS3D (Huret et al. 2013) provided climatologies computed over a 28-yr-long time series (1980-2008). For the North Sea, a 1980-2008 hindcast simulation of ECOSMO II (Daewel \& Schrum 2013) was used, while in the Norwegian Sea, climatologies were computed from a 1995-2003 hindcast using the Nutrient-Phytoplankton-ZooplanktonDetritus (NPZD) module of the ecosystem model NORWECOM.E2E (Hjøllo et al. 2012).

The time series serving as model forcing were computed by horizontally averaging over the domain areas (see Fig. 1). For the Aegean Sea, we only considered the continental shelf (depth $<250 \mathrm{~m}$ ), which is representative of the habitat for the local anchovy population. In the Bay of Biscay, anchovy is also mostly distributed over the continental shelf over its life cycle, except for the juvenile stage, when they are mainly found off-shelf in the south of the bay (Boyra et al. 2013). We thus averaged over the entire geographic area that encompasses the potential habitat of the Bay of Biscay population. In the North Sea, anchovy has been widely distributed since the mid-1990s (Alheit et al. 2012, Petitgas et al. 2012) over the geographic area defined in Fig. 1. The seasonal variability in the distribution of the local populations and the associated spatial variability in temperature and zooplankton biomass were not directly considered in this study. However, because of the high spatial variability of the environment within the North Sea, we examined separately the northern deep and southern shallow parts of this region, on the basis of the $50 \mathrm{~m}$ depth isobath that corresponds approximately to $56^{\circ} \mathrm{N}$ latitude.

Vertical averaging was performed in the same way for each of the regions, based on the following considerations. Anchovy spawn at the sea surface in the Bay of Biscay and in the Aegean Sea when the water column is stratified, i.e. from spring to the end of summer in the Bay of Biscay (Motos et al. 1996, Huret et al. 2018), and from spring to autumn in the Aegean Sea (Somarakis et al. 2004). The egg and larval stages are mostly found in the surface mixed layer. Therefore, temperature forcing for these life stages was computed for the surface mixed layer between 0 and $30 \mathrm{~m}$. Adult anchovies are known to remain close to the bottom during daytime in the Bay of Biscay and the Aegean Sea, or below the thermocline, and move up at night during the spawning season (Massé et al. 1996, Tsagarakis et al. 2012). The temperature forcing for adults was therefore computed as the average temperature between 0 and $150 \mathrm{~m}$. Boyra et al. (2013) described the progressive deepening of juvenile distribution with size in the Bay of Biscay. For this transition stage, temperature was linearly interpolated between the time-series used for early life stages and adults based on the maturity energy level $E_{\mathrm{H}}$. The latter varies between $E_{\mathrm{H}}{ }^{\mathrm{J}}$ at metamorphosis and $E_{\mathrm{H}}{ }^{\mathrm{P}}$ at puberty (see 'The life cycle model', below). Zooplankton climatologies were compiled by averaging the 0-50 m surface layer.

\subsection{The life cycle model}

Development and growth of anchovy were forced by the regional temperature and zooplankton seasonal cycle and modelled over the entire life cycle of an individual in each of the regions. For the egg and yolk-sac larvae, development rates were estimated from temperature relationships as proposed by Regner (1996) for the former stage and Boussouar et al. (2001) for the latter stage. From mouth opening 
onwards, the DEB model (Kooijman 2010) was used (see below).

Fish model configurations are similar between regions, except for 2 reproductive traits for which observations justify some adaptation (see Table 1): spawning season and relative batch fecundity. Spawning season may extend from early spring to end of autumn in the Mediterranean Sea, but spawning activity mostly occurs between May and August in the Aegean Sea. In the Bay of Biscay, spawning starts in April but, also here, major spawning activity spans from May to August. In the North Sea, fewer observations of spawning activity are available, but spawning most likely extends from June to August. European anchovy spawning is generally observed above $12-13^{\circ} \mathrm{C}$ (Peck et al. 2013) in surface waters. The start of the spawning season defined among regions in our model is consistent with this temperature threshold, considering the seasonal variability of surface temperature as proposed in our study (see 'Results'). No external driver other than temperature is generic enough across regions to model the start or end of the spawning season. Internal drivers based on bioenergetics, such as energy density, which is at a minimum in spring at the start of the spawning season and at a maximum towards its end, cannot explain the spawning phenology alone. For these reasons, and because our climatological forcing from regionally averaged fields can only provide rough estimations of environmental conditions triggering spawning, we preferred a more robust approach

Table 1. Regional values for a selected set of anchovy traits (morphology, reproduction seasonality and fecundity) available from observations and as constrained in the model, or as emerging from the model (number of batches and total fecundity). For mean size [weight] at age 3, see 'Materials and methods: Fish data'

\begin{tabular}{|c|c|c|c|c|}
\hline $\begin{array}{l}\text { Mean size }(\mathrm{cm}) \\
\text { [weight }(\mathrm{g}) \text { ] } \\
\text { at age } 3\end{array}$ & $\begin{array}{l}\text { Main } \\
\text { spawning } \\
\text { season }\end{array}$ & $\begin{array}{l}\text { Relative batch } \\
\text { fecundity } \\
\text { (eggs } \mathrm{g}^{-1} \text { fish) }\end{array}$ & $\begin{array}{l}\text { No. of } \\
\text { batches }\end{array}$ & $\begin{array}{l}\text { Total fecundity } \\
\text { over life cycle } \\
\text { (no. of eggs) }\end{array}$ \\
\hline \multicolumn{5}{|l|}{ Aegean Sea } \\
\hline $14[21.8], \mathrm{n}=3862$ & May-Aug ${ }^{\mathrm{a}}$ & $260^{\mathrm{d}}$ & 99 & 372364 \\
\hline \multicolumn{5}{|l|}{ Bay of Biscay } \\
\hline $17[38], \mathrm{n}=10446$ & May-Aug ${ }^{\mathrm{b}}$ & $478.9^{\mathrm{e}}$ & 54 & 691867 \\
\hline \multicolumn{5}{|l|}{ North Sea } \\
\hline $19.8[50], \mathrm{n}=5449$ & $\mathrm{Jun}^{-\mathrm{Aug}^{\mathrm{c}}}$ & $\begin{array}{l}478.9 \text { (based } \\
\text { on Biscay) }\end{array}$ & 52 & 942350 \\
\hline $\begin{array}{l}\text { Norwegian Sea } \\
-\end{array}$ & $\begin{array}{l}\text { Jun-Aug } \\
\text { ed on North Sea) }\end{array}$ & $\begin{array}{c}478.9 \\
\text { (based on Biscay) }\end{array}$ & 22 & 227551 \\
\hline \multicolumn{5}{|c|}{ 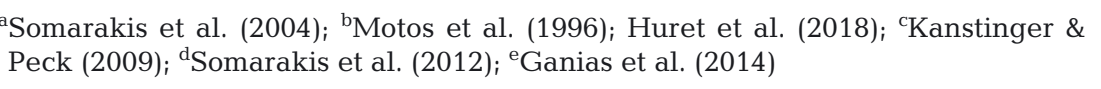 } \\
\hline
\end{tabular}

based on regional observation patterns, as detailed above and in Table 1. In order to compare growth patterns, the simulated individuals have their birth date set to 1 June, which can be considered as within the peak spawning season for all regions. Subsequently, each individual spawns during its life cycle depending on the regional definition of the spawning season. The relative batch fecundity is set to 478.9 eggs $\mathrm{cm}^{-3}$ for the Bay of Biscay as well as for the North Sea, for which no information is available, and 260 eggs $\mathrm{cm}^{-3}$ for the Aegean Sea.

\subsection{The Dynamic Energy Budget (DEB) model}

The DEB model has already shown its efficiency in, for example, simulating oyster growth across various ecosystems (Alunno-Bruscia et al. 2011), and abundance increase and expansion towards the north over recent decades in the northeast Atlantic (Thomas et al. 2016). Furthermore, it was used to understand the mechanisms behind the recent spatio-temporal shift in the distribution of sole and plaice in the North Sea (Teal et al. 2012). In the Bay of Biscay, an updated DEB parameterisation for anchovy, and a new one for sardine, recently allowed for a comparison of biological traits between the 2 species (Gatti et al. 2017).

Following standard DEB theory (Kooijman 2010), the assimilation of energy from the food $(X)$ fills a reserve buffer $(E)$, from which a fixed fraction $\kappa$ of the energy is allocated to the structure of the body $(V)$ through growth on the one hand, and to maturity $\left(E_{\mathrm{H}}\right.$ before first maturity) or reproduction buffer $\left(E_{\mathrm{R}}\right)$ on the other hand (Fig. 2). Somatic and maturity maintenances take priority over growth and reproduction in the allocation of energy reserves. The dynamics of $E$ is key in the DEB theory and is under the influence of food abundance and the kinetics of reserve allocation, processes that are modulated by temperature. Variability in environmental conditions, especially the seasonality in temperate ecosystems, modulates the quantity of reserve $E$. When not enough energy is available from the reserve buffer to sustain maintenance, 


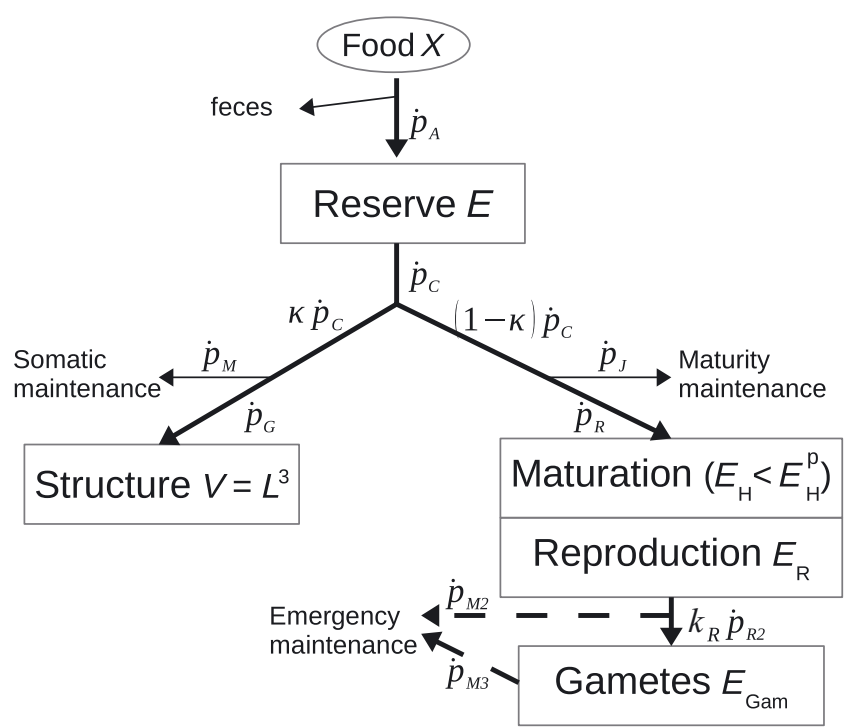

Fig. 2. Conceptual diagram of the anchovy Dynamic Energy Budget (DEB) model. Parameter definition and values are provided in Gatti et al. (2017). Thick lines: main energy fluxes within the organism; thin lines: energy fluxes lost or used for maintenance of the organism; dashed lines: emergency maintenance from the reproduction buffer or atresia, when allocation from reserve cannot sustain somatic and maturity maintenances

the individual dies. Death may occur in winter due to lack of food (starvation), but also in warm areas (or seasons) where (or when) maintenance costs are high and food is not sufficient. Since $E$ has a different energy density than $V$ and $E_{\mathrm{R}}$, this allows energy density of organisms to vary through time. The batch frequency is dynamic $\left(0.25 \mathrm{~d}^{-1}\right.$ on average) depending on temperature and energy in $E_{\mathrm{R}}$ that controls the kinetics of energy allocation to gametes (see Fig. 2 and Gatti et al. 2017).

Our DEB model was calibrated in the Bay of Biscay as detailed in Gatti et al. (2017), with a large set of length, weight and energy density data for an average individual spawned on 1 June, representative of the observed population in the area. A complete list of parameters and their values is available in Gatti et al. (2017). The model was able to realistically simulate growth over the full life cycle, the seasonal variability in energy density, as well as the reproduction patterns in terms of timing and quantity of eggs (Gatti et al. 2017). The food limitation $f$ is calculated using a Holling type II functional response:

$$
f=\frac{X}{\left(X+K_{\mathrm{X}}\right)}
$$

with $K_{\mathrm{X}}$ the half saturation coefficient for resource $X$. Food limitation $f$ affects the assimilation rate $\dot{p}_{A}\left(\mathrm{~J} \mathrm{~d}^{-1}\right)$ through the following formula:

$$
\dot{p}_{A}=\left\{\dot{p}_{A m}\right\} \cdot f \cdot V^{2 / 3}=a e \cdot\left\{\dot{p}_{X m}\right\} \cdot f \cdot V^{2 / 3}
$$

with $\left\{\dot{p}_{A m}\right\}$ and $\left\{\dot{p}_{X m}\right\}$ the area-specific maximum assimilation rate and maximum ingestion rate (both in $\mathrm{J} \mathrm{cm}^{-2} \mathrm{~d}^{-1}$ ), respectively, and ae the assimilation efficiency. All rates in the DEB model are modulated by temperature, depending on the Arrhenius temperature $T_{\mathrm{A}}$ (Kooijman 2010) using the following function:

$$
f(T)=\exp \left(\frac{T_{\mathrm{A}}}{T_{\text {ref }}}-\frac{T_{\mathrm{A}}}{T}\right)
$$

with $f(T)$ the correction applied to any rate at absolute temperature $T$ (in Kelvin) and $T_{\text {ref }}$ a chosen reference temperature at which the rate is unchanged.

When running the bioenergetics model in all target regions with unchanged model parameters, the estimated results were not fully satisfactory when compared to observations. The simulated individual in the North Sea could not survive through its first winter, while the individual in the Aegean Sea, reaching a smaller size than the individual in the Bay of Biscay, as expected, was too big when compared to the actual length and weight data collected in this area. Generally, faster growth with latitude is enabled by several co-varying processes that maximise energy acquisition, including increased standard metabolism, food consumption and conversion efficiency, and foraging activity (Conover et al. 2009). In the DEB model structure we have several parameters allowing the implementation of this adjustment, such as $K_{\mathrm{X}}$, ae and $\left\{\dot{p}_{X m}\right\}$. In order to keep the anchovy bioenergetics unchanged (as far as this is possible) between regions-for easier comparison of the effects of environmental factors, and also because the degrees of freedom are too high for a full calibration of the DEB parameters given the limited availability of data in different regions - only one parameter was allowed to change for the regional calibration. Thus $\left\{\dot{p}_{A m}\right\}$, as a linear function of ae and $\left\{\dot{p}_{X m}\right\}$, was selected. A $\left\{\dot{p}_{A m}\right\}$ value of $884 \mathrm{~J} \mathrm{~cm}^{-2} \mathrm{~d}^{-1}$ was adopted in the Bay of Biscay (Gatti et al. 2017). This was reduced in the Aegean Sea $\left(778 \mathrm{~J} \mathrm{~cm}^{-2} \mathrm{~d}^{-1}\right)$ and increased in the North Sea $\left(982 \mathrm{~J} \mathrm{~cm}^{-2} \mathrm{~d}^{-1}\right)$. If anchovy were to extend to the Norwegian Sea, we would expect it to originate from the North Sea population. Thus we selected the same $\left\{\dot{p}_{A m}\right\}$ value for these 2 regions.

In the DEB model, the ratio $[E]=E: V$ is called the reserve density. The maximum reserve density $\left[E_{\mathrm{m}}\right]$ of an organism is constrained by the ratio of 2 model parameters $\left(\left[E_{m}\right]=\left\{\dot{p}_{A m}\right\}: \dot{V}\right.$, with $\dot{v}$ the energy conductance). [ $E_{\mathrm{m}}$ ] equals $1804 \mathrm{~J} \mathrm{~cm}^{-3}$ for our anchovy 
model (Gatti et al. 2017). Before their first winter, energy in the reproduction buffer is negligible. The ratio of the reserve density and the maximum reserve density $\left(e=[E]:\left[E_{\mathrm{m}}\right]\right.$, called the scaled reserve density) is then a good indicator of the condition of the individuals before their first winter. The same indicator was used to compare the condition of individuals, born throughout the year (every month) in the different regions, at the end of their first year. Even though spawning for some of these months has never been reported, we performed these simulations precisely to investigate the potential link between seasonal spawning strategy and risk of juvenile mortality during their first winter.

\subsection{Quantifying the regional environmental influence on growth variation}

The sources of phenotypic variation in a quantitative character $\left(V_{\mathrm{P}}\right)$ can be partitioned as $V_{\mathrm{P}}=V_{\mathrm{G}}+$ $V_{\mathrm{E}}+V_{\mathrm{G} \times \mathrm{E}}+2 \operatorname{Cov}(\mathrm{G}, \mathrm{E})$ (Conover et al. 2009). $V_{\mathrm{G}}$ is the variance due to genotypic effects, $V_{E}$ is the variance due to environmental influences representing the phenotypic plasticity, $V_{\mathrm{G} \times \mathrm{E}}$ is the interaction term, and $\operatorname{Cov}(\mathrm{G}, \mathrm{E})$ is the covariance between genotypic and environmental effects. Here, we do not have the means of disentangling all these different components, which would require common-garden experiments on individuals of known genetic relationships (Conover et al. 2009). However, the model allows independent testing of some of the sources of variation (here, the different environmental factors) of some phenotypes (here, the growth in length across regions). We quantified the following effects: $\Delta_{\mathrm{P}}=\Delta_{\mathrm{T}}+\Delta_{\mathrm{Z}}+\Delta_{\mathrm{G}}{ }^{*}$, with $\Delta_{\mathrm{P}}$ the phenotypic change across regions, $\Delta_{\mathrm{T}}$ the part of the growth variation due to temperature, $\Delta_{\mathrm{Z}}$ the part due to zooplankton, and $\Delta_{\mathrm{G}}$. the part of the variation due to all other components comprising a genotype effect, alone, in interaction or as a covariable. The reference growth is chosen as the modelled growth in the Bay of Biscay $\left(G_{\text {Biscay }}\right)$, where the DEB model was originally calibrated. Different cross-environment scenarios were performed with the same $\left\{\dot{p}_{A m}\right\}$ value from the Bay of Biscay, combining either the Bay of Biscay temperature with the Aegean Sea (or North Sea) zooplankton or the Bay of Biscay zooplankton with the Aegean Sea (or North Sea) temperature. For each scenario, the mean relative difference was calculated as $\Delta_{\mathrm{S}}=$ mean $\left(\left[G_{\text {region, }}-G_{\text {Biscay }}\right] / \mathrm{G}_{\text {Biscay }}\right)$ over all time steps of the modelled life cycle, with region being either the Aegean or the North Sea, and $S$ either temperature or zooplankton. The total effect $\Delta_{\mathrm{P}}$ was calculated between the fitted regional growth and the reference growth of the Bay of Biscay. Finally, $\Delta_{\mathrm{G}}$. was calculated as the difference between all other components, and results from the regional $\left\{\dot{p}_{A m}\right\}$ calibration. All factors of variation were normalised so that $\Delta_{\mathrm{P}}=1$, and thus effects are comparable across regions. The sign of variation is positive when the effect of variation is in the same direction as the phenotypic variation.

\section{RESULTS}

\subsection{Seasonal variability of temperature and zooplankton}

Daily climatologies of temperature (extracted from the regional hydrodynamic models; Fig. 3) display the seasonal variability, with similar sinusoidal patterns in both surface $(0-30 \mathrm{~m})$ and deeper $(0-150 \mathrm{~m})$ layers, which were used for early life stages and adults, respectively. While winter temperatures are similar in the 2 layers, surface stratification in summer decouples the surface from the deeper layers. In the surface layer, the mean annual temperature and magnitude of its seasonal variability decreases from southern to northern regions (see Table 2), except in the North Sea, where shallow waters allow only a limited buffering effect with respect to the atmospheric temperature. This is best exemplified by the distinction between the southern shallow and the northern deeper North Sea, which feature different seasonal amplitudes, the southern North Sea being colder in winter and warmer in summer than the northern North Sea. The phasing of the seasonal variability is almost similar between the regions, with maximum temperatures in late August (a few weeks earlier in the North Sea) and minimum temperatures in early March (1 mo later in the Norwegian Sea).

Daily climatologies of zooplankton biomass show a different pattern (Fig. 4), with the magnitude of the seasonal variability strongly increasing from south to north (see Table 2). In winter, the concentration remains above $8 \mathrm{mg} \mathrm{C} \mathrm{m}{ }^{-3}$ in the Aegean Sea while it drops to very low values in other regions. The Mediterranean is known as an oligotrophic region; however, anchovy habitat in the Aegean Sea is mostly restricted to areas where river nutrient inputs are supplied throughout the year, and there is not strong light limitation due to 

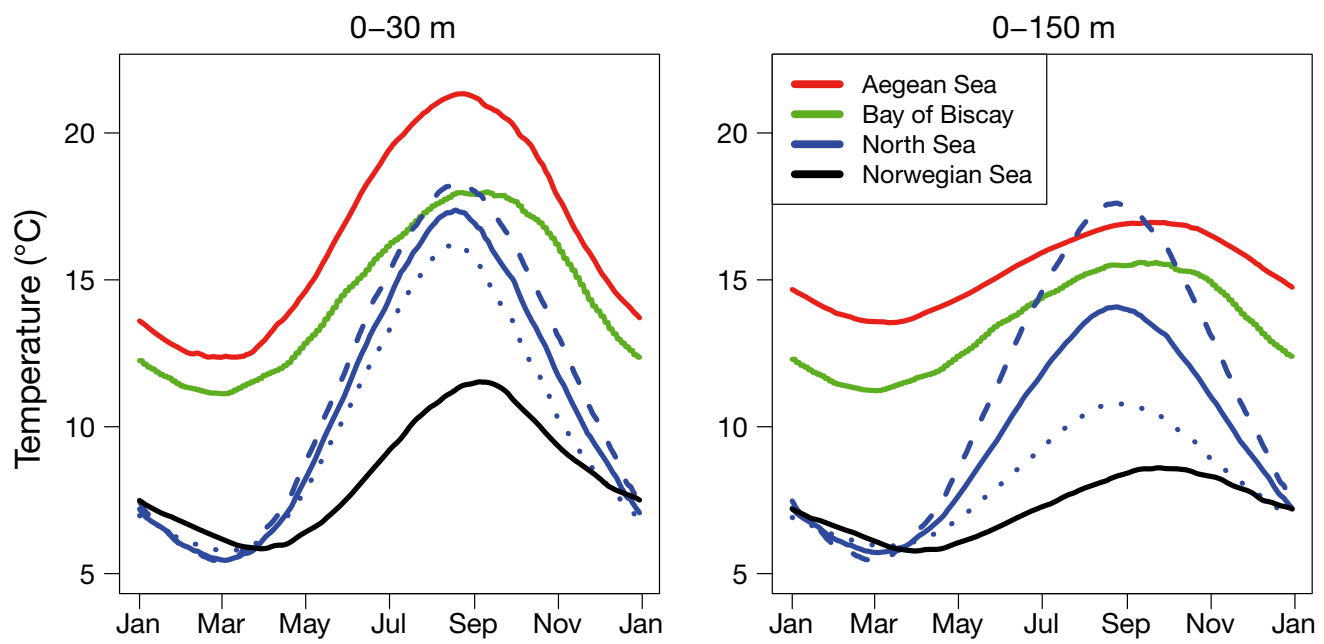

Fig. 3. Daily climatologies of temperature in the different regions in the surface layer (0-30 m, left) and throughout the water column (0-150 m, right). Dashed and dotted blue lines are for the southern and northern North Sea, respectively. See

'Materials and methods: Environmental forcing' for details on the period used to build the climatology

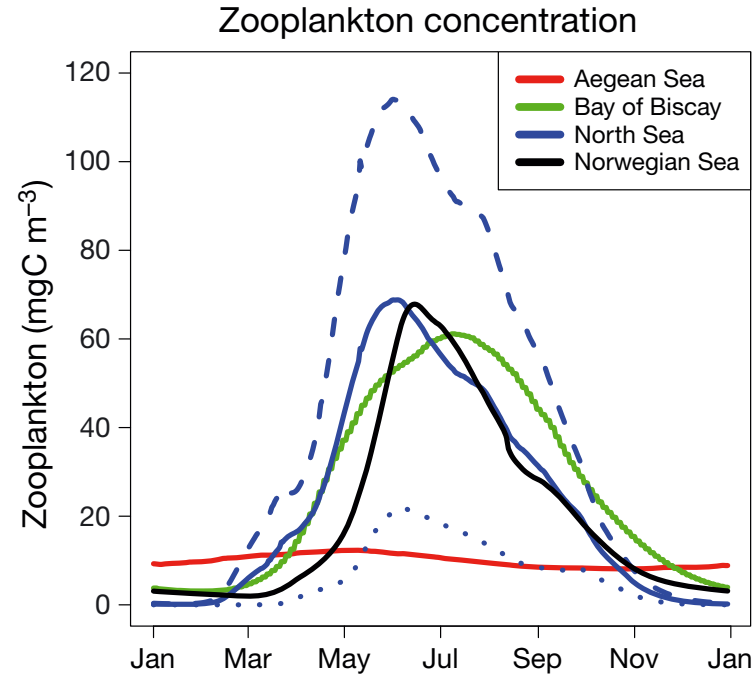

Fig. 4. Daily climatologies of zooplankton biomass in the different regions for the surface layer $(0-50 \mathrm{~m})$. Dashed and dotted blue lines are for the southern and northern North Sea, respectively. See 'Materials and methods: Environmental forcing' for details on the period used to build the climatology the low latitude. The duration and phasing of the productive season also vary substantially between regions. Duration decreases from south to north, from continuous low production in the Aegean Sea, to an April to October period in the Bay of Biscay, an April to September period in the North Sea, and a May to October period in the Norwegian Sea. When combining the patterns for duration and magnitude of zooplankton biomass, we find a dome-shaped relationship between annually averaged zooplankton biomass and latitude, with the highest values at intermediate latitudes in the Bay of Biscay and the North Sea (Table 2). Again, in the North Sea, the southern and northern regions feature very different zooplankton biomass and seasonality. The shallow southern part appears highly productive with the largest mean annual biomass (42.3 $\mathrm{mg} \mathrm{C} \mathrm{m}^{-3}$ ) among our study regions, as well as the largest seasonal variability $\left(113.9 \mathrm{mg} \mathrm{C} \mathrm{m}^{-3}\right)$ and largest duration of the productive season (March to November).

Table 2. Environmental conditions from the regional coupled physical-biogeochemical models. The North Sea was split to account for the large spatial heterogeneity in the environmental conditions. The anchovy Dynamic Energy Budget model was calibrated between regions with adjustment of the maximum assimilation rate $\left\{\dot{p}_{A m}\right\}$

\begin{tabular}{|c|c|c|c|c|c|}
\hline \multirow[t]{2}{*}{ Region } & \multicolumn{2}{|c|}{$\begin{array}{l}\text { Annual surface } \\
\text { temperature }\left({ }^{\circ} \mathrm{C}\right)\end{array}$} & \multirow{2}{*}{$\begin{array}{l}\text { Mean annual } \\
\text { zooplankton bio- } \\
\text { mass }\left(\mathrm{mg} \mathrm{C} \mathrm{m}^{-3} \text { ) }\right.\end{array}$} & \multirow{2}{*}{$\begin{array}{l}\text { Seasonal magnitude } \\
\text { of zooplankton bio- } \\
\text { mass }\left(\mathrm{mg} \mathrm{C} \mathrm{m}^{-3}\right)\end{array}$} & \multirow[t]{2}{*}{$\begin{array}{l}\text { Fitted }\left\{\dot{p}_{A m}\right\} \\
\left(\mathrm{J} \mathrm{cm}^{-2} \mathrm{~d}^{-1}\right)\end{array}$} \\
\hline & Mean & Range & & & \\
\hline Aegean Sea & 15.5 & 5.7 & 9.9 & 4.3 & 778 \\
\hline Bay of Biscay & 14.4 & 6.9 & 27.5 & 58 & 884 \\
\hline North Sea (southern) & $10.7(11.4)$ & $11.9(12.9)$ & $24.4(42.3)$ & $68.7(113.9)$ & (982) \\
\hline Norwegian Sea & 8.3 & 9 & 21 & 65.8 & 982 \\
\hline
\end{tabular}



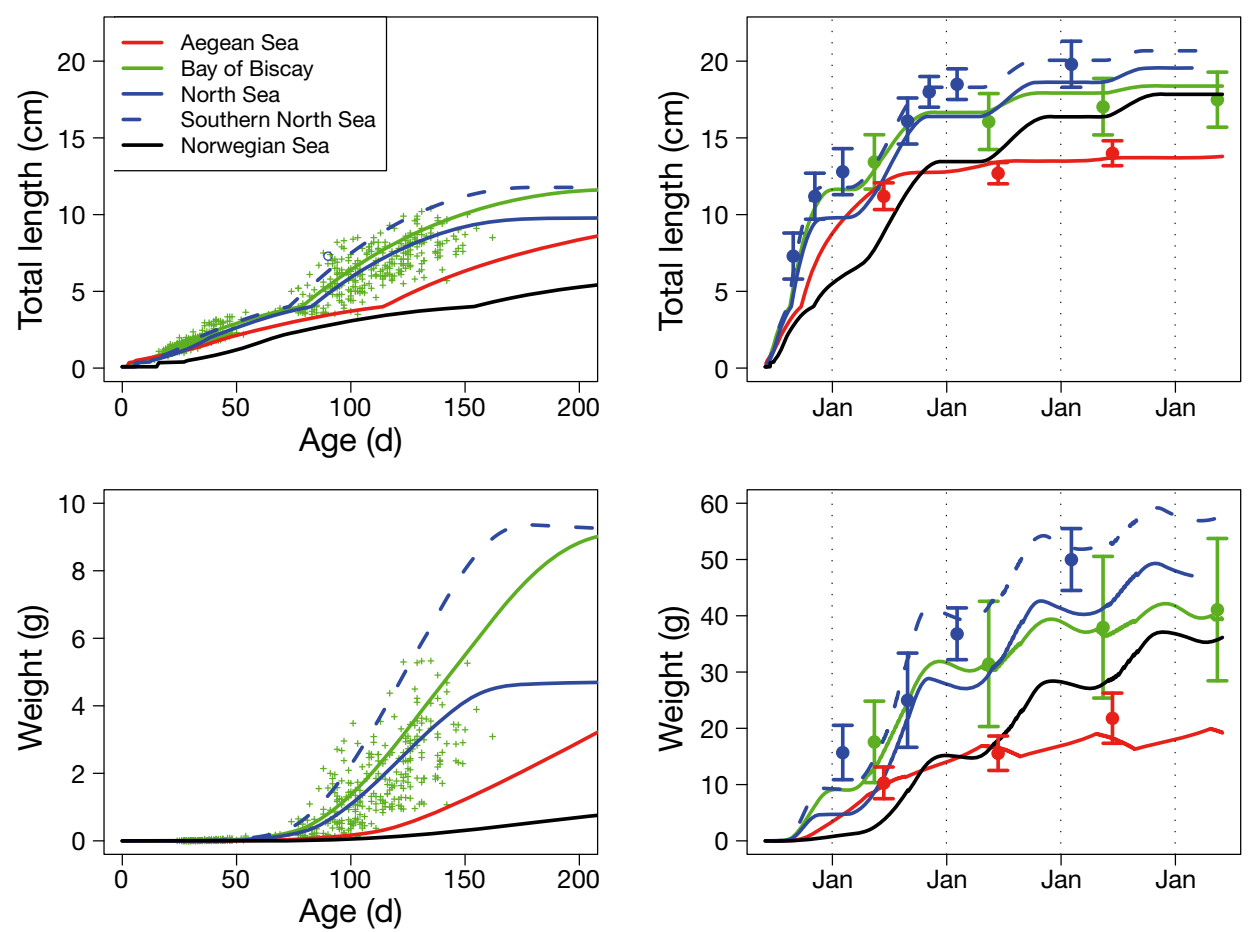

Fig. 5. Growth as modelled with regional climatology forcing from birth on 1 June. Length and weight at age are represented in the top and bottom panels, respectively, with a focus on larval and juvenile stages in the left panels and the full life-cycle in the right panels. Average values at age from regional data are shown as dots with \pm 1 SD (see 'Materials and methods: Fish data'). Green crosses: individual values from the Bay of Biscay at larval and juvenile stages; open circle: average juvenile size in the North Sea at approximately $90 \mathrm{~d}$. The North Sea curve is cut when individuals die from starvation during the first winter.

'Jan' refers to January of the successive years

\subsection{Patterns of growth}

The regional length- and weight-at-age data reveal significantly different growth patterns (Fig. 5, Table 1). For the Aegean Sea, anchovy size is consistently smaller than in other regions, while in the Bay of Biscay and the North Sea this is relatively similar up to age 2. Adult growth is low in the Aegean Sea, where individuals reach an average length (weight) of $14 \mathrm{~cm}(21.8 \mathrm{~g})$ at age 3, while growth seems faster in the Bay of Biscay, where individuals reach $17 \mathrm{~cm}$ ( $38 \mathrm{~g})$ on average at age 3 . Growth is even faster in the North Sea, where length (weight) at age 3 is $19.8 \mathrm{~cm}(50 \mathrm{~g})$. Variability (standard deviation) of length and weight is on average higher at all ages in the Bay of Biscay as compared to the North Sea and the Aegean Sea.

Once the model was fitted with the calibration of $\left\{\dot{p}_{A m}\right\}$ (Table 2), we were able to simulate-starting from an egg spawned on 1 June - the fish growth in length and weight in all 3 regions where anchovy is present. In the North Sea, the simulated anchovy was able to survive, with good fit to observations, only under the environmental conditions from the south- ern North Sea. In the northern and entire North Sea, individuals died of starvation during winter at age 1 and 3, respectively. Reserves became insufficient to sustain maintenance throughout the winter before the following increase in food availability in spring. Hence, only the southern North Sea is discussed hereafter. The growth curves were always within one standard deviation from the mean length- or weightat-age data, except for the weight after the first winter in the North Sea, where it was slightly underestimated (Fig. 5). At the larval stage, growth curves showed limited differences, which were exacerbated at the juvenile stage, when simulated Aegean Sea anchovy fit to the smallest sizes observed in the Bay of Biscay, and simulated North Sea anchovy fit to some of the largest observations (Fig. 5). In the Aegean Sea, most of the growth occurs during the first year of life, with the model predicting growth throughout the first winter. In the following years, growth occurs at the beginning of the year, and weight loss occurs during the summer. In the other areas, growth in length stops during winter, when the individual loses weight. Growth mostly occurs from late spring throughout the summer, and is more signifi- 

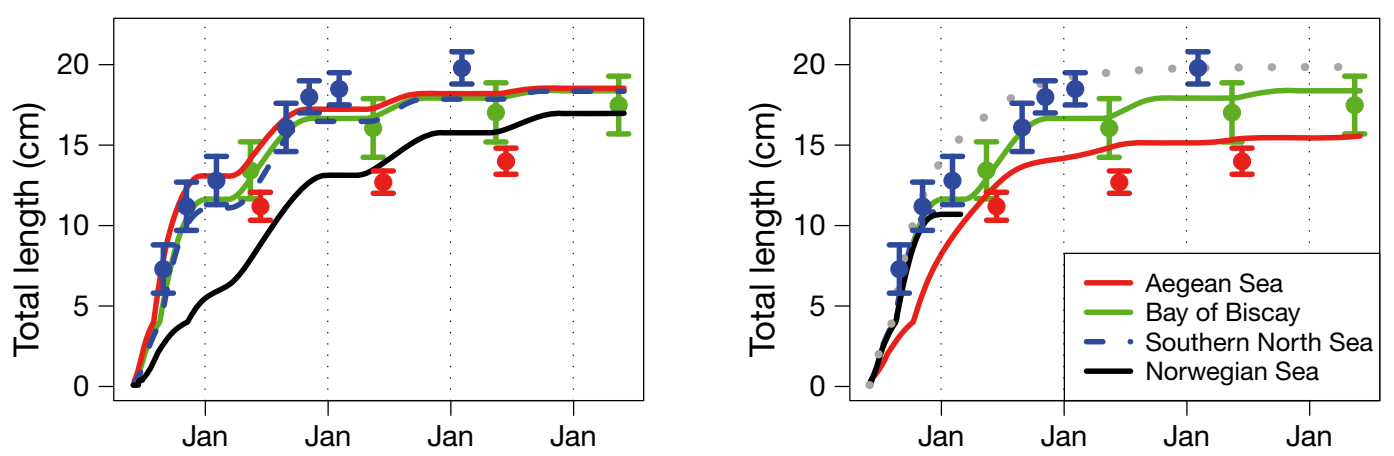

Fig. 6. Growth in length under different environmental scenarios from birth on 1 June. Left: Bay of Biscay food with temperature from the respective regions. Right: Bay of Biscay temperature with food from the respective regions, or without food limitation (grey dotted curve). The North and Norwegian Seas curves are cut when individuals die from starvation during the first winter. 'Jan' refers to January of the successive years

cant at ages 1 and 2. In the Norwegian Sea, the simulated individual is able to survive, but with a very limited growth rate. This effect is primarily due to major temperature limitations, but a sustained growth would enable the individual to eventually reach the average observed size in the Bay of Biscay at age 4 .

The cross-environment scenarios illustrate the effect of individual environmental factors on the growth variation between the Bay of Biscay, as reference, and the other regions (Fig. 6). A higher temperature in the Aegean Sea than in the Bay of Biscay increases growth rate until age 1 , whereas a lower temperature in the North and Norwegian Seas slows down the growth rate. On the other hand, the anchovy size converges towards the same maximum length at age 3-4, except for the Norwegian Sea, where growth is too low to reach its model asymptotic size over a life span of 4 yr. The effect of zooplankton is the opposite, as can be seen especially for the Aegean Sea, since North Sea and Norwegian Sea individuals die during their first winter, when using the non-adapted $\left\{\dot{p}_{A m}\right\}$ of the Bay of Biscay. When using the Aegean Sea zooplankton biomass, the growth rate and maximum size are lower than when using zooplankton biomass from the Bay of Biscay. The observations and our model suggest a slight food limitation in the southern North Sea (Fig. 5), at the scale of the life cycle, since the maximum size reached in this region is similar to the one obtained in the non food-limitation scenario (see Fig. 6). The quantification of the respective effects highlights the opposite impacts of these 2 environmental variables on anchovy growth, with a stronger effect of zooplankton $\left(\Delta_{\mathrm{Z}}=0.77\right.$ and 0.84 for the Aegean and the North Sea, respectively) than temperature $\left(\Delta_{\mathrm{T}}=\right.$ -0.31 and -0.64$)$. The unexplained part of the growth variation is assigned to genetic adaptation, in our case the $\left\{\dot{p}_{A m}\right\}$ adjustment $\left(\Delta_{\mathrm{G}^{*}}=0.54\right.$ and 0.80 for the Aegean and North Seas, respectively). Note that the validity of these relative effects is limited in the North Sea, where for the food scenario growth does not cover the whole life cycle, and we do not provide any quantification for the Norwegian Sea, where no data are available to support our model fitting.

\subsection{Patterns of energy dynamics}

The bioenergetics model allows for a deeper understanding of the growth patterns, looking at the energy dynamics among the DEB model compartments throughout the life cycle (Fig. 7). Structure directly refers to size, and thus provides similar seasonal and life cycle patterns (dark area in Fig. 7). The dynamics of the reserve buffer, together with the reproduction buffer and, to a lesser extent, gametes, explain the seasonal changes of fish weight represented in Fig. 5. In the Aegean Sea, the energy in the reserve buffer is almost stable, except for a very slight decrease in summer, hence weight loss in summer is instead due to spawning. In the Bay of Biscay, and more markedly in the North Sea, the weight loss during winter is due to the negative net variation of the dynamics of the reserve buffer. In these 2 regions, the reserve replenishes from spring to autumn, but weight increases essentially after the reproductive season. As a consequence, the maximum energy density, which mostly depends on the variation of the reserve buffer, occurs during spring before reproduction in the Aegean Sea, whereas it occurs during autumn in the northern regions.

The simulated scaled reserve density before the first winter is shown in Fig. 8. In each region, it is highest for individuals born (according to the simula- 

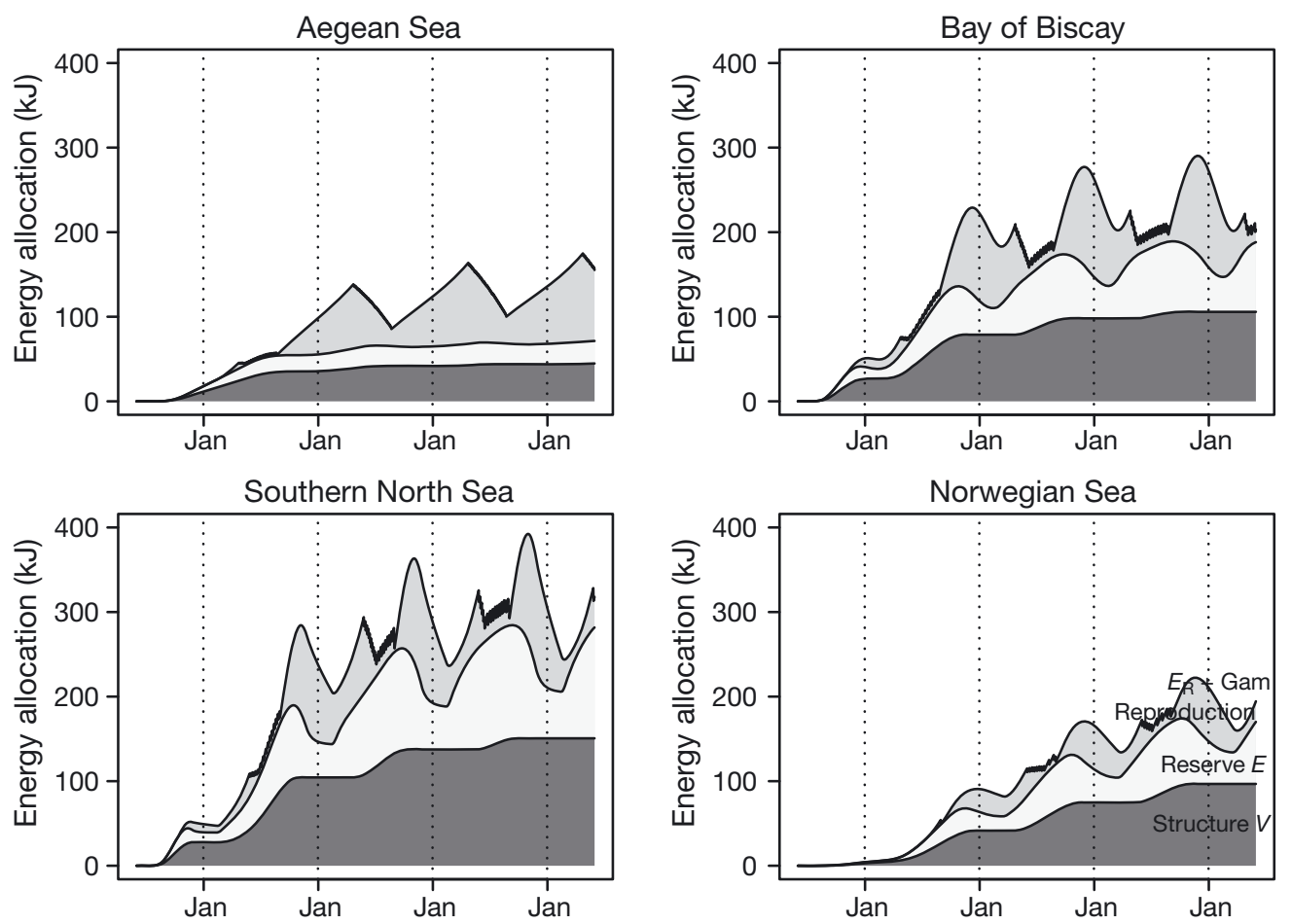

Fig. 7. Energy as modelled with regional climatology forcing in the 4 Dynamic Energy Budget (DEB) compartments of Fig. 2 throughout the life cycle of an individual born on 1 June. Dark grey represents the individual structure $(V)$, light grey represents the reserve buffer $(E)$, and mid-grey represents the reproductive buffer $\left(E_{\mathrm{R}}\right)$ and gametes $\left(E_{\mathrm{Gam}}\right)$. For clarity, $E_{\mathrm{R}}$ and $E_{\mathrm{Gam}}$ were not separated. $E_{\mathrm{Gam}}$ varies around $10 \mathrm{~kJ}$ during the reproductive season, when spawning events are revealed by small indentations. 'Jan' refers to January of the successive years

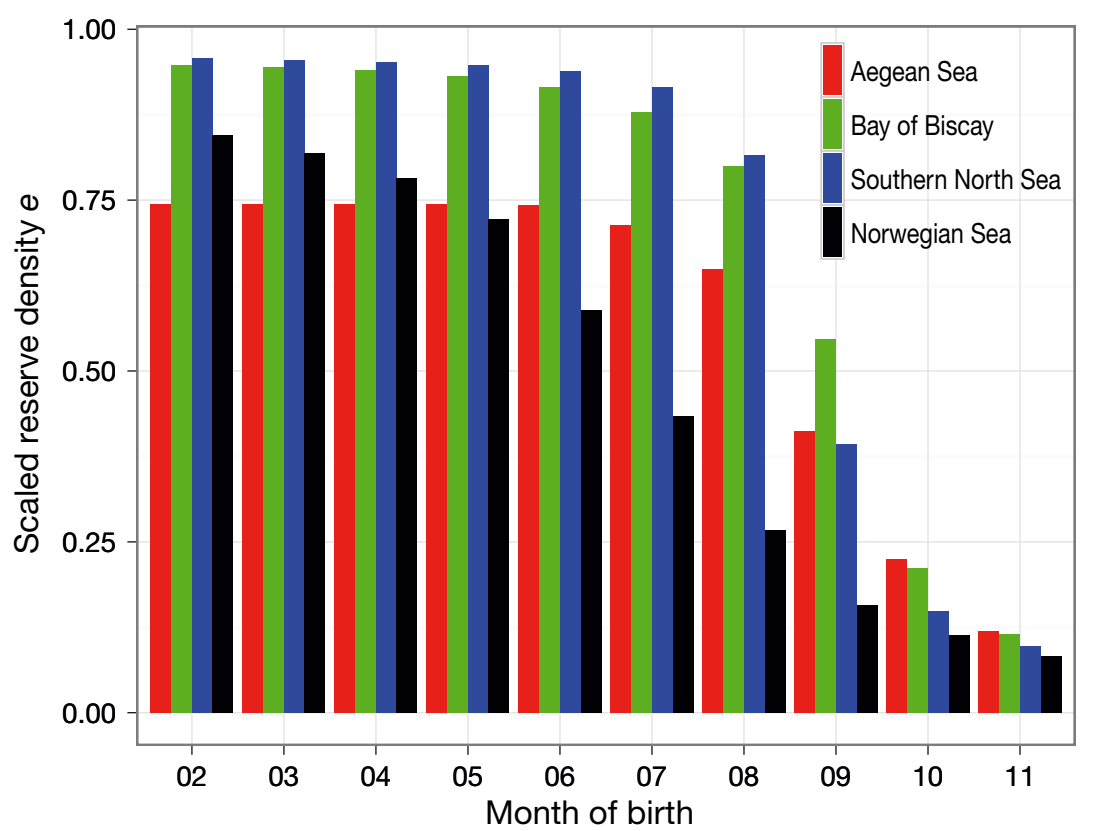

Fig. 8. Scaled reserve density $\left(e=[E]:\left[E_{\mathrm{m}}\right]\right.$; see 'Materials and methods: The DEB model') just before the first winter. This indicator reflects the condition of the juvenile fish at a period of the year when condition should be at its highest (as close as possible to 1) so that the fish is able to overwinter. It is provided for model simulations from birth on successive months (1st of the month) with regional climatology forcing tion) at the beginning of the year, because they have had a maximum amount of time to build reserves. The scaled reserve density decreases progressively and becomes lowest for late-born individuals that would still be in their larval development stage during the first winter. Anchovy in the North Sea and the Bay of Biscay can almost reach their maximum scaled reserve density during their first year (0.96 and 0.95 , respectively), while it only reaches 0.74 for anchovy in the Aegean Sea. The decrease in cumulated reserves is slow in all regions for individuals born until July, except for the Norwegian Sea, where it continuously decreases from the beginning to the end of the year. From August onwards, the decrease becomes substantial in all regions, and faster from northern to southern regions, so that the latitudinal gradient of scaled reserve density before winter is reversed as compared to individuals born at the 
beginning of the year (Fig. 8). For individuals born in September, scaled reserve density only reaches 0.5 in the Bay of Biscay, and in October it never reaches 0.25 in any of the regions.

\subsection{Patterns of reproduction}

Size at first maturity varies weakly among regions, with an increasing trend with latitude, i.e. $10.18 \mathrm{~cm}$ (Aegean Sea), $10.35 \mathrm{~cm}$ (Bay of Biscay) and $10.39 \mathrm{~cm}$ (North Sea). The DEB model estimated reproduction potential over the life cycle, as detailed in Table 1. The number of batches is maximum in the Aegean Sea, minimum in the Norwegian Sea, and the Bay of Biscay and the North Sea have similar numbers of batches. The total number of eggs, however, reveals a maximum total fecundity in the North Sea, followed by the Bay of Biscay; fecundity is lowest in the Norwegian and Aegean Seas. The combination of a warmer environment and lower relative batch fecundity in the Aegean Sea explains the largest number of released batches. Differences in total fecundity can then be explained by considering fish size, on which batch fecundity directly depends.

\section{DISCUSSION}

\subsection{Environmental seasonality}

The latitudinal pattern from our coupled models is in agreement with the global pattern of intensification of seasonality towards the north, both in temperature and planktonic production. As presented at the global scale and for the North Atlantic (Racault et al. 2012), our models predict a higher peak production, a delayed initiation and a shorter duration of the productive season towards the north. The North Sea appears as an anomaly in the continuous south-tonorth gradient. Indeed, seasonal variability is exacerbated, initiation has the same timing as in the Bay of Biscay, and peak production reaches the same values as in the Norwegian Sea. This is caused by the interactions between strong tides and the bathymetry, which is shallower towards the southern North Sea. Hence, the water column is well mixed throughout the year in this sub-region, making light and nutrient limitation less critical factors for phytoplankton production (Daewel \& Schrum 2013). In addition, the southern North Sea features high nutrient loads from the large continental rivers, and a rapid temperature increase during spring in shallow waters. The North
Sea illustrates the strong environmental gradient, exhibited at a regional scale, that may be opportunistically exploited by fish, based on its energetic tradeoffs, at a seasonal scale.

The hindcast simulations providing temperature and zooplankton biomass are not built exactly on the same periods, although they partly overlap and span at least over 20 yr for the Aegean Sea, the Bay of Biscay and the North Sea, making these climatologies representative of the regional conditions. A warming trend has been described over this time period, but was limited to an increase of about $1^{\circ} \mathrm{C}$ from 1985 to 2004 in the surface waters of the North Sea, where it was at its highest (Holt et al. 2012), and therefore appears as a second-order process as compared to the spatial gradient in temperature between our target regions. Regional models have been preferred over global physical-biogeochemical coupled models, because of the higher spatial and temporal resolution required in the modelling of shelf seas, the consideration of region-specific processes and parameterisations in the model formulation, and the availability of model skill assessment in our regions of interest.

\subsection{Evolutionary adaptation of anchovy across latitudes}

The environment alone could not fully explain the different growth patterns observed across regions when using the set of parameters calibrated on the Bay of Biscay data. In the North Sea, as a whole or by sub-regions, individuals either did not survive their first winter or grew too slowly, while in the Aegean Sea, individuals grew too fast. Adjusting only one parameter (the maximum assimilation rate) within a range of $10 \%$ from the Bay of Biscay value enabled the model to reproduce these regional growth patterns. In another bioenergetics modelling study, with available experimental data on the physiology of Atlantic silversides, Munch \& Conover (2002) made several parameters vary, on average by $28 \%$, to obtain the best fit of their model to the growth of distinct populations from different latitudes.

Increasing the $\left\{\dot{p}_{A m}\right\}$ value in northern regions results in a higher potential of energy acquisition and, consequently, an increase in growth and maximum body size. The increase of growth with latitude is generally described as a physiological adaptation that compensates for temperature decrease and reduction of the duration of the productive season (Conover et al. 2009). This negative covariance between a genetic adaptation and an environmental 
gradient is known as the countergradient variation (Conover et al. 2009). European anchovy is structured genetically in different populations (Zarraonaindia et al. 2012). It is thus likely that adaptation to local environments may have led to optimised seasonal growth towards northern latitudes. Our results also agree with a size- or energy-selective winter mortality to explain the observed countergradient variation in growth (Schultz \& Conover 1999), since without parameter adaptation, individuals from the northernmost regions were dying during their first winter. Towards northern latitudes, the duration of the productive season becomes shorter, and accumulating enough reserves to survive over the winter becomes challenging, which would explain the required compensation effect in growth.

Local genetic adaptation may be the justification for adjustment of other model parameters. Generally, faster growth with latitude is enabled by several covarying processes that maximise energy acquisition, which could involve other DEB parameters. However, this exercise would have highly increased the degrees of freedom in the calibration process, with a lack of constraint considering the lack of data in most regions. Thus, comparison between regions is easier and more rigorous with the fewest number of adjusted parameters. Nonetheless, we tested the regional calibration of another parameter alone, the half saturation coefficient for food $K_{\mathrm{X}}$, with similar success as with $\left\{\dot{p}_{A m}\right\}$, as well as similar growth patterns in the results. Fitted values ranged from $0.87 \mathrm{mg} \mathrm{C} \mathrm{m}^{-3}$ in the North Sea to $2.61 \mathrm{mg} \mathrm{C} \mathrm{m}^{-3}$ in the Bay of Biscay and $4.17 \mathrm{mg} \mathrm{C} \mathrm{m}^{-3}$ in the Aegean Sea. In comparison, Alunno-Bruscia et al. (2011) had their $K_{\mathrm{X}}$ vary between $260 \times 10^{3}$ and $700 \times 10^{3}$ cells l $^{-1}$ of phytoplankton to fit their oyster DEB model, in ecosystems with less variance than ours (their model spanned only conditions from the Bay of Biscay to the English Channel). Finally, we tested whether the Arrhenius temperature $T_{\mathrm{A}}$, which affects all physiological rates, could be a parameter leading to an adaptation to regional temperature. This was not successful, as individuals' growth in the Aegean Sea was never sufficiently reduced to fit the data, and individuals in the North Sea could never have survived their first winter. This does not mean that thermal adaptation does not exist, but rather that it is not sufficient without an additional adaptation through processes related to energy acquisition.

In addition to its evolutionary interpretation, the adjustment of $\left\{\dot{p}_{A m}\right\}$ across regions may also reflect inconsistencies between regional model configurations. First, we used different physical-biogeochemical models that may not be fully consistent when compared together in a common area. Moreover, the forcing we used did not consider any temporal variation in the horizontal distribution of anchovy, but only in its vertical distribution at different life stages. Yet, distinctive sub-regions in the North Sea have shown the large impact this simplification may have on the environment and, consequently, on the growth pattern. Second, food biomass shows some seasonality, but fish need energy, not biomass. In our model, the energy density of the zooplankton is fixed, although it does change throughout the zooplankton size range and throughout the year, especially at high latitudes, where lipid accumulation is essential for overwintering (Sundby et al. 2016), but also in less extreme environments (e.g. in the Mediterranean, Barroeta et al. 2017). A better description of the winter zooplankton biomass, as well as its seasonal variability in size and energy density, would improve the accuracy of the bioenergetics model simulations across contrasted areas.

\subsection{Reassessing the role of food versus temperature}

An increase in temperature and food availability results in an increase in the instantaneous growth rate and maximum body size, respectively (see separated effects in Fig. 6). When environmental conditions become severe, temperature may also limit the maximum size reached by anchovy at age $3-4$, and food may limit growth rate over the full life cycle. When mean annual food and temperature feature an opposite latitudinal gradient of variation, the influence of food seems to dominate the impact of the 2 variables, as growth rate increases with latitude, similar to the food gradient, but opposite to the temperature gradient. Moreover, we have seen that local adaptation must be taken into account in our latitudinal comparison. The cross-environment scenarios confirmed the countergradient variation in growth with temperature or length of the growing season, but also highlighted a cogradient variation in growth with food concentration. Overall, our model predicts that the observed phenotypic variation in anchovy growth across northeastern European waters is more related to food than to temperature. Indeed, the simulated phenotypic plasticity of growth is stronger with food than with temperature, and the genetic adaptation was made through a food-related parameter (the maximum assimilation rate) rather than a temperature-related one (the Arrhenius temperature). Without considering the cogradient variation of 
food, countergradient thermal adaptation would have to be far overestimated to alone explain growth variability across latitude.

Overall, our model predicts a strong food limitation in the Aegean Sea over the whole life cycle, with slight weight loss during the warm summer, when maintenance requirements are high and not sustained by the relatively low food concentrations. In the North Sea and, to a lesser extent, in the Bay of Biscay, food limitation only occurs during winter with weight loss through reserve depletion, but temperature is the limiting factor of growth in these 2 regions. The maximum size that anchovy can reach-i.e. with no food limitation $(f=1)$, and given our set of parameters for the DEB model - is $L_{\infty}=19.9 \mathrm{~cm}$, a value similar to our estimated average size at age 3 in the North Sea. Our simulation in the North Sea results in a size $L_{\mathrm{m}}=19.3 \mathrm{~cm}$ at age 3, again highlighting the low food limitation over the life cycle in that area.

\subsection{Seasonality in energy dynamics}

The DEB theory predicts that the latitudinal trend in environmental food conditions results in increasing maximum body size with latitude (van der Veer et al. 2003). The varying environmental patterns with latitude may explain much more of the seasonal patterns in some of the fish biological traits. In the Aegean Sea at the adult stage, the model predicts that growth mostly occurs in spring before and at the beginning of the spawning season, while growth is stopped and weight loss can even occur during summer. In the Bay of Biscay and the North Sea, growth mostly occurs during summer, towards the end of and after the reproductive season. In the latter regions, the reserve buffer is filled in autumn to prepare for the winter, while it is almost constant throughout the year in the Aegean Sea. The model predicts a positive latitudinal gradient in energy density before winter from the Aegean to the North Sea, a feature that was described for both anchovy and sardine between the Bay of Biscay and the English Channel (Gatti et al. 2018). This pattern was described as an adaptive allocation strategy to the seasonal variability with latitude, under a size-selective winter mortality constraint (Schultz \& Conover 1999). In the Northwestern Mediterranean, energy density is highest in spring and lowest in autumn (Albo-Puigserver et al. 2017), while in the Bay of Biscay it is lowest at the end of the winter-spring period and highest in autumn (Dubreuil \& Petitgas 2009, Gatti et al. 2018). This sea- sonal variability in energy density follows the seasonal variability in food availability in the respective regions. Our DEB model further suggests that in the Mediterranean Sea, as the reserve buffer fluctuates only slightly, reproduction may be the dominant factor of seasonal variability in energy density of the whole organism. In the northern regions, the model indicates that the opposite might be occurring, with the effect of reproduction on energy density being negligible and difficult to discriminate from environmental effects. The body-size scaling relationship with latitude, which summarises all of these patterns that the DEB model can reproduce, eventually emerges from the trade-off between bioenergetics and environment productivity and seasonality.

\subsection{Emergent patterns in reproductive traits}

Variation in size at maturity with latitude is a common feature among clupeids (Ganias et al. 2014), for instance, with sizes at maturity between 10.9 and $16.8 \mathrm{~cm}$ for sardine in European waters (Silva et al. 2006). Our simulated gradient in size at maturity is very weak, yet consistent with the general observed pattern. We lack a quantitative description across different regions for anchovy. Our model also suggests an increase in fecundity with latitude (except for the Norwegian Sea), even though the spawning season is restricted to 3 mo (June-August) in the North Sea. However, so far, no information is available to validate this pattern. If true, our findings would indicate that the low abundance of anchovy in the North Sea can only be explained by high mortality, especially at the larval and juvenile stages. Indeed, the reduced mortality with larger windows of opportunity at the egg and larval stages (Petitgas et al. 2012), combined with better juvenile conditions entering the winter (Raab et al. 2013), were the proposed explanations for the increased abundances of anchovy in the North Sea observed during recent decades.

The spawning phenology must also be linked to the bioenergetics of organisms and, indirectly, to the environmental seasonality. The start of the spawning season for anchovy may be triggered by a temperature threshold or stratification setup (Motos et al. 1996), or by cumulated degree days since wintertime (Huret et al. 2018). For an income-breeder such as the anchovy (McBride et al. 2015), the spawning season must be related to the productive season of the ecosystem. The match-mismatch hypothesis (Cushing 1990) also involves a temporal overlap between the larvae and their prey. These temperature and 
food requirements may underpin the initiation of the spawning season, and could explain observations indicating earlier spawning in March in the Aegean Sea (Ganias et al. 2014), which is characterised by higher temperatures and an earlier bloom in spring, as compared to April in the Bay of Biscay.

However, far less information is available on the processes that could end the protracted spawning season of anchovy. Growing and accumulating enough reserves as juveniles to prepare and survive the first winter is clearly critical (Schultz \& Conover 1999, Sundby et al. 2016). We propose that the accumulated energy before the first winter, or scaled reserve density (see Fig. 8), which is strongly linked to the birth date, is a good indicator of survival during next winter. We do not propose any objective threshold values to be able to survive the first winter. However, if they exist, they must be region dependent. For example, Figs. $7 \& 8$ show that in the Aegean Sea, the minimum energy required to survive the first winter is obviously less than in the northern regions. For birth dates from 1 September onwards, reserve density is far reduced compared to earlier spawned individuals (Fig. 8). This could be an evolutionary explanation for the negligible egg concentrations observed from September to the end of the year in the Bay of Biscay. In the Aegean Sea, the decrease in reserve density from summer to autumn is less, which could explain the extended spawning season until early autumn. In summary, the spawning season could be initiated by a temperature or a bioenergetics threshold, while the end of the spawning likely depends on the capacity of offspring to build sufficient reserves required to survive their first winter. These hypotheses are consistent between observations in our study regions and model predictions.

\subsection{Why is there no anchovy population in the Norwegian Sea?}

Our model predicts that, at first glance, closing the life cycle in the Norwegian Sea is possible: individuals may survive the winter and eventually reproduce. However, practically, and considering the additional constraints not explicitly parameterised in our model, we can explain the absence of anchovy in that region. First, a review of temperature conditions for European anchovy spawning (Peck et al. 2013) gave a range between $11.6^{\circ} \mathrm{C}$ and $27.5^{\circ} \mathrm{C}$. This minimum temperature found for observed anchovy eggs lies close to the maximum temperature reached in the surface waters of the Norwegian Sea at the end of
August based on the climatology shown in Fig. 3. This would result in a very short spawning window, only occurring in warm years considering the interannual variability. Second, the simulated growth rate is the slowest among all regions, even during the summer season, especially during the larval and juvenile stages. Based on the stage duration mechanism of mortality (Houde 1987), this would give juveniles little chance to survive to adult stage in that region. Accumulating enough energy before the first winter also becomes challenging (Fig. 8), especially when this is combined with the only potential spawning window in August-September. Despite a decreasing length of the productive season from south to north (Fig. 2), the average annual zooplankton biomass increases from the Aegean Sea to the southern North Sea, but then decreases towards the Norwegian Sea. The North Sea could represent the northern limit of a temperate system where anchovy is constrained spatially based on its bioenergetics. Third, organisms have a temperature tolerance range. What would happen to anchovy living in waters far below $10^{\circ} \mathrm{C}$, which is the minimum temperature found in the Bay of Biscay? Anchovies are able to survive in the North Sea during winter, if they migrate north along the Scottish coast, and some probably in the English Channel, where conditions are milder. Temperature modulates all processes in our bioenergetics model. Applying an adapted formulation for the temperature correction function (see Eq. 3), as proposed by Kooijman (2010), when outside the temperature optimal or suboptimal range, or a lethal temperature if it exists, would add realism to our regional study at its northern edge.

\section{CONCLUSIONS}

Analysing variation in biological traits of marine species along latitudinal gradients is a difficult task, because of the interaction and covariance between phenotypic plastic responses and genetic adaptation to local environmental conditions. A lack of availability of coherent information over a large spatial domain, on both biological traits and environmental conditions, also often hinders robust comparison. Yet, a correct description of the spatial or temporal variability under different climate regimes is key in developing an ecosystem approach to fisheries management.

Among the increasing number of studies looking at spatial trait variation with latitude, few are based on modelling studies allowing a cause-and-effect understanding of the mechanisms involved. Modelling 
cannot replace common-garden or transplant experiments, which are the proper way of analysing geneticadaptation. But it can help to extrapolate environmental conditions outside the observational domain and timing. Moreover, performing numerical experiments can help disentangle the different sources of trait variation. Here-after gathering comprehensive information on growth and environmental information from the Aegean Sea, the Bay of Biscay and the North Sea - the modelling of anchovy bioenergetics, with a common set of parameters except one, proved generic enough to simulate in a realistic way the observed variability in the average growth patterns and reproduction strategies (quantity, timing) along the European latitudinal gradient where it is distributed.

Seasonality in temperature and food explained most of the variation in the timing of growth and reproduction of anchovy across regions. Increased magnitude of seasonality, with a longer winter involving low planktonic production towards northern latitudes, seems to be the main evolutionary driver of optimised growth adaptation. The main constraint is therefore that fish must accumulate a minimum amount of reserve energy to survive winter, particularly at the beginning of the life cycle. However, our results also describe a cogradient variation of growth with annually averaged food biomass. High productivity in high latitudes compensates for lower temperature and strong seasonality, so that the cogradient variation of growth with food biomass would be higher than the countergradient variation of growth with temperature, eventually reducing the requirement for local genetic adaptation. The complex effects of food resources on spatial variation of traits may have been overlooked in past studies.

Averaging environmental forcing at the regional scale has the effect of smoothing the environment perceived by the fish; so does the use of a climatological forcing, which tends to increase the duration of the productive season and decrease its intensity (Platt et al. 2009). Further work should investigate the effect of the interannual and within-region spatial variability on the response of the fish biological traits. Indeed, Politikos et al. (2015a) showed that seasonal movement within the Bay of Biscay had some bioenergetics causes and effects. From that perspective, information on the seasonal spatial distribution of fish within regions would be highly valuable.

Models, either statistical or mechanistic, are increasingly used in projections of climate change impacts on fish population distribution and dynamics. Our modelling study calls for caution, however, since the responses of different traits at the scale of the life cycle may be highly complex. Survival under environmental seasonality and bioenergetics tradeoffs is far from a linear response. Besides, genetic adaptation is a constant background process that calls for parameter adjustment in model extrapolation across regions or across temporal regimes. Clearly, comprehensive modelling studies integrating forecasted changes in temperature and food (with a special focus on the latter), their interaction through, e.g. change in plankton phenology, and the potential for evolutionary adaptation of populations, should form the basis of future studies investigating the impact of climate change on fish populations.

Acknowledgements. This study was initiated under the SEAMAN project of the EU FP7 ERA-NET SEASERA (all authors), and finalized under the EU H2020 CERES project (IFREMER authors). We are indebted to all the people involved in fish data collection at sea, biometry and age reading from otoliths, as well as to those involved in the development and validation of the coupled physical-biogeochemical models. We thank the two anonymous reviewers, the guest editor and C. Lebigre, who greatly contributed to improving our manuscript with constructive comments and corrections.

\section{LITERATURE CITED}

Albo-Puigserver M, Muñoz A, Navarro J, Coll M, Pethybridge H, Sánchez S, Palomera I (2017) Ecological energetics of forage fish from the Mediterranean Sea: seasonal dynamics and interspecific differences. Deep Sea Res II 140:74-82

Alheit J, Pohlmann T, Casini M, Greve W and others (2012) Climate variability drives anchovies and sardines into the North and Baltic Seas. Prog Oceanogr 96:128-139

* Alunno-Bruscia M, Bourlès $\mathrm{Y}$, Maurer D, Robert $\mathrm{S}$ and others (2011) A single bio-energetics growth and reproduction model for the oyster Crassostrea gigas in six Atlantic ecosystems. J Sea Res 66:340-348

Barroeta Z, Olivar MP, Palomera I (2017) Energy density of zooplankton and fish larvae in the southern Catalan Sea (NW Mediterranean). J Sea Res 124:1-9

* Beare D, Burns F, Jones E, Peach K and others (2004) An increase in the abundance of anchovies and sardines in the north-western North Sea since 1995. Glob Change Biol 10:1209-1213

Bergmann C (1847) Über die Verhältnisse der Wärmeökonomie der Thiere zu ihrer Grösse. Göttinger Studien 3: 595-708

*Bhattacharya CG (1967) A simple method of resolution of a distribution into Gaussian components. Biometrics 23: 115-135

* Borme D, Tirelli V, Brandt SB, Fonda Umani S, Arneri E (2009) Diet of Engraulis encrasicolus in the northern Adriatic Sea (Mediterranean): ontogenetic changes and feeding selectivity. Mar Ecol Prog Ser 392:193-209

* Boussouar A, Le Bihan S, Arino O, Prouzet P (2001) Mathematical model and numerical simulations of the migra- 
tion and growth of Biscay Bay anchovy early larval stages. Oceanol Acta 24:489-504

Boyra G, Martínez U, Cotano U, Santos M, Irigoien X, Uriarte A (2013) Acoustic surveys for juvenile anchovy in the Bay of Biscay: abundance estimate as an indicator of the next year's recruitment and spatial distribution patterns. ICES J Mar Sci 70:1354-1368

* Cheung WWL, Sarmiento JL, Dunne J, Froelicher TL and others (2013) Shrinking of fishes exacerbates impacts of global ocean changes on marine ecosystems. Nat Clim Chang 3:254-258

Conover DO, Present TMC (1990) Countergradient variation in growth rate: compensation for length of the growing-season among Atlantic silversides from different latitudes. Oecologia 83:316-324

Conover DO, Duffy TA, Hice LA (2009) The covariance between genetic and environmental influences across ecological gradients. Ann N Y Acad Sci 1168:100-129

Cushing D (1990) Plankton production and year-class strength in fish populations: an update of the match/ mismatch hypothesis. Adv Mar Biol 26:249-293

* Daewel U, Schrum C (2013) Simulating long-term dynamics of the coupled North Sea and Baltic Sea ecosystem with ECOSMO. II. Model description and validation. J Mar Syst 119-120:30-49

Doray M, Petitgas P, Huret M, Duhamel E and others (2018) Monitoring small pelagic fish in the Bay of Biscay ecosystem, using indicators from an integrated survey. Prog Oceanogr 166:168-88

Dubreuil J, Petitgas P (2009) Energy density of anchovy Engraulis encrasicolus in the Bay of Biscay. J Fish Biol 74: 521-534

Edwards M, Richardson AJ (2004) Impact of climate change on marine pelagic phenology and trophic mismatch. Nature 430:881-884

Ganias K, Somarakis S, Nunes C (2014) Reproductive potential. In: Ganias K (ed) Biology and ecology of sardines and anchovies. CRC Press, Boca Raton, FL, p 79-121

Gatti P, Petitgas P, Huret M (2017) Comparing biological traits of anchovy and sardine in the Bay of Biscay: a modelling approach with the Dynamic Energy Budget. Ecol Modell 348:93-109

Gatti P, Cominassi L, Duhamel E, Grellier P and others (2018) Bioenergetic condition of anchovy and sardine in the Bay of Biscay and English Channel. Prog Oceanogr 166:129-138

Hjøllo SS, Huse G, Skogen MD, Melle W (2012) Modelling secondary production in the Norwegian Sea with a fully coupled physical/primary production/individual-based Calanus finmarchicus model system. Mar Biol Res 8: 508-526

Holt J, Hughes S, Hopkins J, Wakelin SL and others (2012) Multi-decadal variability and trends in the temperature of the northwest European continental shelf: a modeldata synthesis. Prog Oceanogr 106:96-117

Houde ED (1987) Fish early life dynamics and recruitment variability. Am Fish Soc Symp 2:17-29

Huret M, Sourisseau M, Petitgas P, Struski C, Léger F, Lazure P (2013) A multi-decadal hindcast of a physicalbiogeochemical model and derived oceanographic indices in the Bay of Biscay. J Mar Syst 109-110:S77-S94

Huret M, Bourriau P, Doray M, Gohin F, Petitgas P (2018) Survey timing vs. ecosystem scheduling: degree-days to underpin observed interannual variability in marine ecosystems. Prog Oceanogr 166:30-40
ICES (2010) Report of the Workshop on Age reading of European anchovy (WKARA). 9-13 November 2009, Sicily, Italy. ICES CM 2009/ACOM:43

Kanstinger P, Peck M (2009) Co-occurrence of European sardine (Sardina pilchardus), anchovy (Engraulis encrasicolus) and sprat (Sprattus sprattus) larvae in southern North Sea habitats: abundance, distribution and biochemical-based condition. Sci Mar 73:141-152

Kooijman SALM (2010) Dynamic energy budget theory for metabolic organisation, 3rd edn. Cambridge University Press, Cambridge

*Massé J, Koutsikopoulos C, Patty W (1996) The structure and spatial distribution of pelagic fish schools in multispecies clusters: an acoustic study. ICES J Mar Sci 53: 155-160

McBride RS, Somarakis S, Fitzhugh GR, Albert A and others (2015) Energy acquisition and allocation to egg production in relation to fish reproductive strategies. Fish Fish 16:23-57

* Mildenberger TK, Taylor MH, Wolff M (2017) TropFishR: an $\mathrm{R}$ package for fisheries analysis with length-frequency data. Methods Ecol Evol 8:1520-1527

* Mollet FM, Engelhard GH, Vainikka A, Laugen AT, Rijnsdorp AD, Ernande B (2013) Spatial variation in growth, maturation schedules and reproductive investment of female sole Solea solea in the Northeast Atlantic. J Sea Res 84:109-121

*Montero-Serra I, Edwards M, Genner MJ (2015) Warming shelf seas drive the subtropicalization of European pelagic fish communities. Glob Change Biol 21:144-153

Motos L, Uriarte A, Valencia V (1996) The spawning environment of the Bay of Biscay anchovy (Engraulis encrasicolus L.). Sci Mar 60:117-140

*Munch SB, Conover DO (2002) Accounting for local physiological adaptation in bioenergetic models: testing hypotheses for growth rate evolution by virtual transplant experiments. Can J Fish Aquat Sci 59:393-403

Nikolioudakis N, Isari S, Somarakis S (2014) Trophodynamics of anchovy in a non-upwelling system: direct comparison with sardine. Mar Ecol Prog Ser 500:215-229

* Peck MA, Reglero P, Takahashi M, Catalán IA (2013) Life cycle ecophysiology of small pelagic fish and climatedriven changes in populations. Prog Oceanogr 116: 220-245

Perry AL, Low PJ, Ellis JR, Reynolds JD (2005) Climate change and distribution shifts in marine fishes. Science 308:1912-1915

* Petitgas P, Alheit J, Peck MA, Raab K and others (2012) Anchovy population expansion in the North Sea. Mar Ecol Prog Ser 444:1-13

* Petitgas P, Rijnsdorp AD, Dickey-Collas M, Engelhard GH and others (2013) Impacts of climate change on the complex life cycles of fish. Fish Oceanogr 22:121-139

* Platt T, White GN, Zhai L, Sathyendranath S, Roy S (2009) The phenology of phytoplankton blooms: ecosystem indicators from remote sensing. Ecol Modell 220:3057-3069

* Plounevez S, Champalbert G (1999) Feeding behaviour and trophic environment of Engraulis encrasicolus (L.) in the Bay of Biscay. Estuar Coast Shelf Sci 49:177-191

* Politikos DV, Huret M, Petitgas P (2015a) A coupled movement and bioenergetics model to explore the spawning migration of anchovy in the Bay of Biscay. Ecol Modell 313:212-222

* Politikos D, Somarakis S, Tsiaras KP, Giannoulaki M, Petihakis G, Machias A, Triantafyllou G (2015b) Simulating 
anchovy's full life cycle in the northern Aegean Sea (eastern Mediterranean): a coupled hydro-biogeochemical-IBM model. Prog Oceanogr 138:399-416

Raab K, Nagelkerke L, Boeree C, Rijnsdorp A, Temming A, Dickey-Collas M (2011) Anchovy Engraulis encrasicolus diet in the North and Baltic Seas. J Sea Res 65:131-140

Raab K, Llope M, Nagelkerke LAJ, Rijnsdorp AD and others (2013) Influence of temperature and food availability on juvenile European anchovy Engraulis encrasicolus at its northern boundary. Mar Ecol Prog Ser 488:233-245

Racault MF, Le Quéré C, Buitenhuis E, Sathyendranath S, Platt T (2012) Phytoplankton phenology in the global ocean. Ecol Indic 14:152-163

Raybaud V, Bacha M, Amara R, Beaugrand G (2017) Forecasting climate-driven changes in the geographical range of the European anchovy (Engraulis encrasicolus). ICES J Mar Sci 74:1288-1299

Regner S (1996) Effects of environmental changes on early stages and reproduction of anchovy in the Adriatic Sea. Sci Mar 60:167-177

Rose KA, Fiechter J, Curchitser EN, Hedstrom K and others (2015) Demonstration of a fully-coupled end-to-end model for small pelagic fish using sardine and anchovy in the California Current. Prog Oceanogr 138:348-380

Schultz ET, Conover DO (1999) The allometry of energy reserve depletion: test of a mechanism for size-dependent winter mortality. Oecologia 119:474-483

Silva A, Santos MB, Caneco B, Pestana G, Porteiro C, Carrera $P$, Stratoudakis Y (2006) Temporal and geographic variability of sardine maturity at length in the northeastern Atlantic and the western Mediterranean. ICES J Mar Sci 63:663-676

Silva A, Carrera P, Massé J, Uriarte A and others (2008) Geographic variability of sardine growth across the northeastern Atlantic and the Mediterranean Sea. Fish Res 90:56-69

Somarakis S, Palomera I, Garcia A, Quintanilla L, Koutsikopoulos C, Uriarte A, Motos L (2004) Daily Egg Production of anchovy in European waters. ICES J Mar Sci 61: 944-958

Editorial responsibility: Susana Garrido (Guest Editor), Lisbon, Portugal
Somarakis S, Schismenou E, Siapatis A, Giannoulaki M, Kallianiotis A, Machias A (2012) High variability in the Daily Egg Production Method parameters of an eastern Mediterranean anchovy stock: influence of environmental factors, fish condition and population density. Fish Res 117-118:12-21

Sundby S, Drinkwater KF, Kjesbu OS (2016) The North Atlantic spring-bloom system - where the changing climate meets the winter dark. Front Mar Sci 3:28

* Teal LR, van Hal R, van Kooten T, Ruardij P, Rijnsdorp AD (2012) Bio-energetics underpins the spatial response of North Sea plaice (Pleuronectes platessa L.) and sole (Solea solea L.) to climate change. Glob Change Biol 18: 3291-3305

* Thomas Y, Pouvreau S, Alunno-Bruscia M, Barillé L, Gohin $F$, Bryère $P$, Gernez $P$ (2016) Global change and climatedriven invasion of the Pacific oyster (Crassostrea gigas) along European coasts: a bioenergetics modelling approach. J Biogeogr 43:568-579

* Tsagarakis K, Giannoulaki M, Somarakis S, Machias A (2012) Variability in positional, energetic and morphometric descriptors of European anchovy Engraulis encrasicolus schools related to patterns of diurnal vertical migration. Mar Ecol Prog Ser 446:243-258

* Tsiaras KP, Petihakis G, Kourafalou VH, Triantafyllou G (2014) Impact of the river nutrient load variability on the North Aegean ecosystem functioning over the last decades. J Sea Res 86:97-109

*Van Beveren E, Bonhommeau S, Fromentin JM, Bigot JL and others (2014) Rapid changes in growth, condition, size and age of small pelagic fish in the Mediterranean. Mar Biol 161:1809-1822

*van der Veer HW, Kooijman SALM, van der Meer J (2003) Body size scaling relationships in flatfish as predicted by Dynamic Energy Budgets (DEB theory): implications for recruitment. J Sea Res 50:257-272

Zarraonaindia I, Iriondo M, Albaina A, Pardo MA and others (2012) Multiple SNP markers reveal fine-scale population and deep phylogeographic structure in European anchovy (Engraulis encrasicolus L.). PLOS ONE 7:e42201

Submitted: August 16, 2017; Accepted: March 19, 2018 Proofs received from author(s): June 12, 2018 